\title{
Regular Article \\ Effects of the bendazol fungicide on in vitro development of the neem (Azadirachta indica A. JUSS)
}

\author{
Elisabete Pacheco dos Santos, *Robson Antonio de Souza, Maria \\ Jaislanny Lacerda e Medeiros, Gilberto Dias Alves, Laureen Michelle \\ Houllou
}
Plant Tissue Culture Laboratory, Northwest Strategic Technologies Center (CETENE), Cidade Universitária. CEP 50.740 -545. Recife, Pernambuco, Brazil
*Corresponidng author E- mail: robson.souza@cetene.gov.br

Two experiments were conducted to evaluate Bendazol fungicidal effects in neem micropropagation. In these experiments, the nodal segment explants from in vitro plants were used. In the first experiment, the explants remained in DKW culture medium for a period of 30 days containing different concentrations of Bendazol (M1 -50, M2 - 100, M3 200, and M4 - 400 mg. $\mathrm{L}^{-1}$ ). The control treatment (M0) was prepared with DKW medium + BAP $\left(0.225 \mathrm{mg} . \mathrm{L}^{-1}\right)$. In the second experiment, the explants were maintained for only one week in media supplemented with Bendazol or BAP, and then they were transferred and kept in free Bendazol/BAP media for three weeks. In each experiment, the design was completely randomized with five treatments, 10 replicates per treatment, and one explant/cultivation flask. The variables analyzed included the formation of calluses and roots, lateral bud development, shoot height, contamination and plant death. There was no significant difference in tree variables (shoot, callus formation and shoot height) between treatments in both experiments. There was no death, plant contamination and rooting during the experiment. The results indicate that Bendazol can be used at low doses for in vitro neem cloning thereby replacing BAP and ultimately reducing production costs.

Keywords: micropropagation, agrochemicals, low-cost micropropagation

The neem, Azadirachta indica A. Juss., is a woody tree species geographically distributed in the tropics and subtropical world forests. This species belongs to the Meliaceae family and is naturally occurring in India, Pakistan, Sri Lanka, Malaysia, Indonesia, Thailand and Burma (Orwa et al., 2009; Vidigal, 2007).

This species has been the subject of research because of its potential use in the production of bio-insecticides (Rodrigues et al., 2009), biodiesel (Muthu et al., 2010), the cosmetics industry (Neves et al., 2005), disease treatment (Ogbuewu et al., 2011) and in the degraded areas recovery (Paes et al., 2011).

Commercial varieties of neem do not yet exist. Therefore, the development of a more genetically homogeneous material, using superior genotypes as explant source, can be obtained through plant tissue culture techniques (Amaral and Silva, 2003). These techniques are based on the totipotency of plant cells followed by in vitro regeneration (Cabral et al., 2003).

The method of in vitro propagation by vegetative propagules has had a significant impact on agribusiness as an efficient strategy to produce large-scale clones from 
a mother plant in a short time (Souza et al., 2006). Conventional methods of in vitro cloning using commercial cytokinins raise the cost in large-scale production. Therefore, the development of methodologies that promote better performance in the cost / benefit of micro plants is required. One routine strategy for economically viable chemical substitution is the use of agrochemicals, such as fungicides and herbicides (Tiwari et al., 2006).

According to Giladi et al. (1979), beneficial effects were observed on the in vitro and in vivo multiplication of plants when some fungicides and bactericides were incorporated into the culture medium to control contaminants. The effects of some fungicides, such as Benomyl, are similar to those of growth regulators and can stimulate a positive effect in various crops including, tangerine (Moreira, 1993), chrysanthemum (Salgado et al., 2001) and pineapple (Silva et al., 2002). According to Colombo et al. (2004), an increased number of new shoots was observed on in vitro orchid species (Cattleya and Laelia lundii loddigesii) using medium supplemented with Chlorothalonil fungicide. Based on such promising results, the present work aimed to evaluate the effect of Bendazol on neem micropropagation.

\section{Materials and Methods}

Neem fruits were collected at the Agronomic Institute of Pernambuco and taken to the Applied Micropropagation Research Laboratory - LAPAB, located in the Strategic Technology Center of the Northeast - CETENE in Recife / PE, Brazil.

The fruit surface decontamination was performed by immersion in $70 \%$ alcohol for five minutes and subsequent immersion in $1.5 \%$ sodium hypochlorite solution for 10 min.

The fruits were then washed three times with sterile, distilled water. Embryo cotyledons were removed in a laminar flow and inoculated in a test tube containing 10 $\mathrm{ml}$ of DKW medium (Driver and Kuniyuki, 1984). The tubes remained in a growth room with irradiance around $30 \mu \mathrm{M} \cdot \mathrm{m}^{-2} \cdot \mathrm{s}^{-1}$ at $25 \pm 1{ }^{\circ} \mathrm{C}$ and a photoperiod of 16 hours. After 30 days, the in vitro plants were used as donors of explants (nodal segments) in two experiments.

In both experiments, the DKW medium contained $30 \mathrm{~g} \mathrm{~L}^{-1}$ sucrose and was supplemented with either BAP (benzylaminopurine) or Bendazol fungicide according to the treatment. In the control treatment, the standard cultivation medium for neem micropropagation (M0 - DKW + $0.225 \mathrm{mg} \mathrm{L}^{-1} \mathrm{BAP}$ ) was used and there were four concentrations of Bendazol (M1 - 50 mg L-1; M2 - $100 \mathrm{mg} . \mathrm{L}^{-1}$; M3 - $200 \mathrm{mg} . \mathrm{L}^{-1}$ and M4 - 400 mg.L-1). The $\mathrm{pH}$ of the media was adjusted to 5.8, and it was solidified with $6 \mathrm{~g} \mathrm{~L}^{-1}$ agar and distributed in culture flasks before autoclaving at $121{ }^{\circ} \mathrm{C}$ for 20 min.

In both experiments (I and II), the same Bendazol stock solution was used. It was made with $8 \mathrm{ml}$ of Bendazol diluted in $200 \mathrm{ml}$ of distilled water, in which the final concentration was $\mathrm{C}=20 \mathrm{mg}$. $\mathrm{L}^{-1}$.

The nodal neem segments were inoculated in culture flasks containing 30 $\mathrm{ml}$ of medium. In the first experiment, the explants were maintained for a period of 30 days in media containing hormone or Bendazol (M0, M1, M2, M3 and M4). In experiment II, the explants were maintained in media containing hormone or Bendazol for 8 days and then were transferred to a flask containing DKW medium without the addition of the fungicide or plant regulator, where they remained for 22 more days. The experiments were maintained in a growth chamber, and all explants were examined after 30 days of culture (development of lateral bud, callus formation on explant basis, the shoot height, rooting, plant death and contamination).

The experimental design was completely randomized with 10 repetitions per treatment, the experimental unit was represented by a bottle containing a nodal segment. Data were subjected to analysis of variance. When needed, some data were transformed into $(\sqrt{ } \mathrm{x}+0.5)$, and the averages compared by Tukey's test at $5 \%$ 
probability, through ASSISTAT software 7.6 beta (Silva and Azevedo, 2009).

\section{Results}

The variable development of lateral buds present in the nodal segments did not differ statistically significantly between the five treatments (Table 1 and 2). The four different concentrations of Bendazol had no positive or negative effect when compared to standard treatments used in the micropropagation of neem (M0 supplemented with BAP). Yet for this variable, there was no significant difference between the time of exposure of the explants to the fungicide concentrations and growth regulator (30 days - I experiment and 8 days - experiment II).

Callus formation was observed on the explant bases in all treatments regardless of exposure time to fungicide or phytohormone. The calluses maintained in media containing fungicide (M1, M2, M3 and M4) were oxidized (Fig. 1) and possessed a light brown colour and firm consistency. Although there was no significant difference between the treatments, the highest amount of callus formation was observed in M3 treatments with an average of 2.1 in the second experiment (Tables 1 and 2). The amount of callus formation was also higher in explants maintained in the presence or fungicidal hormone for one week (experiment II).

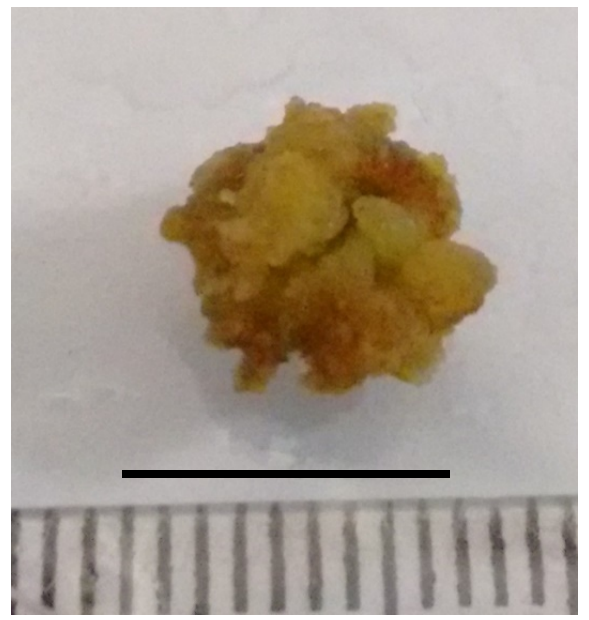

Figure 1. Neem callus with oxidative damage. Bar $=1,0 \mathrm{~cm}$.

Table 1. Development of lateral buds and callus formation of neem shoot height $(\mathrm{cm})$, from nodal segments cultured on DKW with a fungicide or BAP in experiment I.

\begin{tabular}{cccc}
\hline Treatment & $\begin{array}{c}\text { Shoot tips } \\
\text { development }\end{array}$ & Callus formation & Shoot tip size (cm) \\
\hline M0 & $1,5 \mathrm{~A}$ & $1,3 \mathrm{~A}$ & $3,6 \mathrm{~A}$ \\
M1 & $1,5 \mathrm{~A}$ & $1,1 \mathrm{~A}$ & $2,4 \mathrm{~A}$ \\
M2 & $1,5 \mathrm{~A}$ & $1,1 \mathrm{~A}$ & $2,6 \mathrm{~A}$ \\
M3 & $1,5 \mathrm{~A}$ & $0,7 \mathrm{~A}$ & $2,6 \mathrm{~A}$ \\
M4 & $1,4 \mathrm{~A}$ & $1,1 \mathrm{~A}$ & $2,7 \mathrm{~A}$ \\
\hline
\end{tabular}

Means followed by the same letter do not differ amongst themselves $(\mathrm{P} \leq 0.05)$

Table 2. Development of lateral buds and callus formation of neem shoot height $(\mathrm{cm})$, from nodal segments cultured on DKW with a fungicide or BAP in experiment II.

\begin{tabular}{cccc}
\hline Treatment & Shoot tips development & Callus formation & Shoot tip size $(\mathrm{cm})$ \\
\hline M0 & $1.5 \mathrm{~A}$ & $1.2 \mathrm{~A}$ & $4.2 \mathrm{~A}$ \\
M1 & $1.5 \mathrm{~A}$ & $1.2 \mathrm{~A}$ & $2.6 \mathrm{~A}$ \\
M2 & $1.5 \mathrm{~A}$ & $1.4 \mathrm{~A}$ & $2.2 \mathrm{~A}$ \\
M3 & $1.4 \mathrm{~A}$ & $2.1 \mathrm{~A}$ & $2.8 \mathrm{~A}$ \\
M4 & $1.4 \mathrm{~A}$ & $1.1 \mathrm{~A}$ & $2.5 \mathrm{~A}$ \\
\hline
\end{tabular}

Means followed by the same letter do not differ amongst themselves $(\mathrm{P} \leq 0.05)$ 


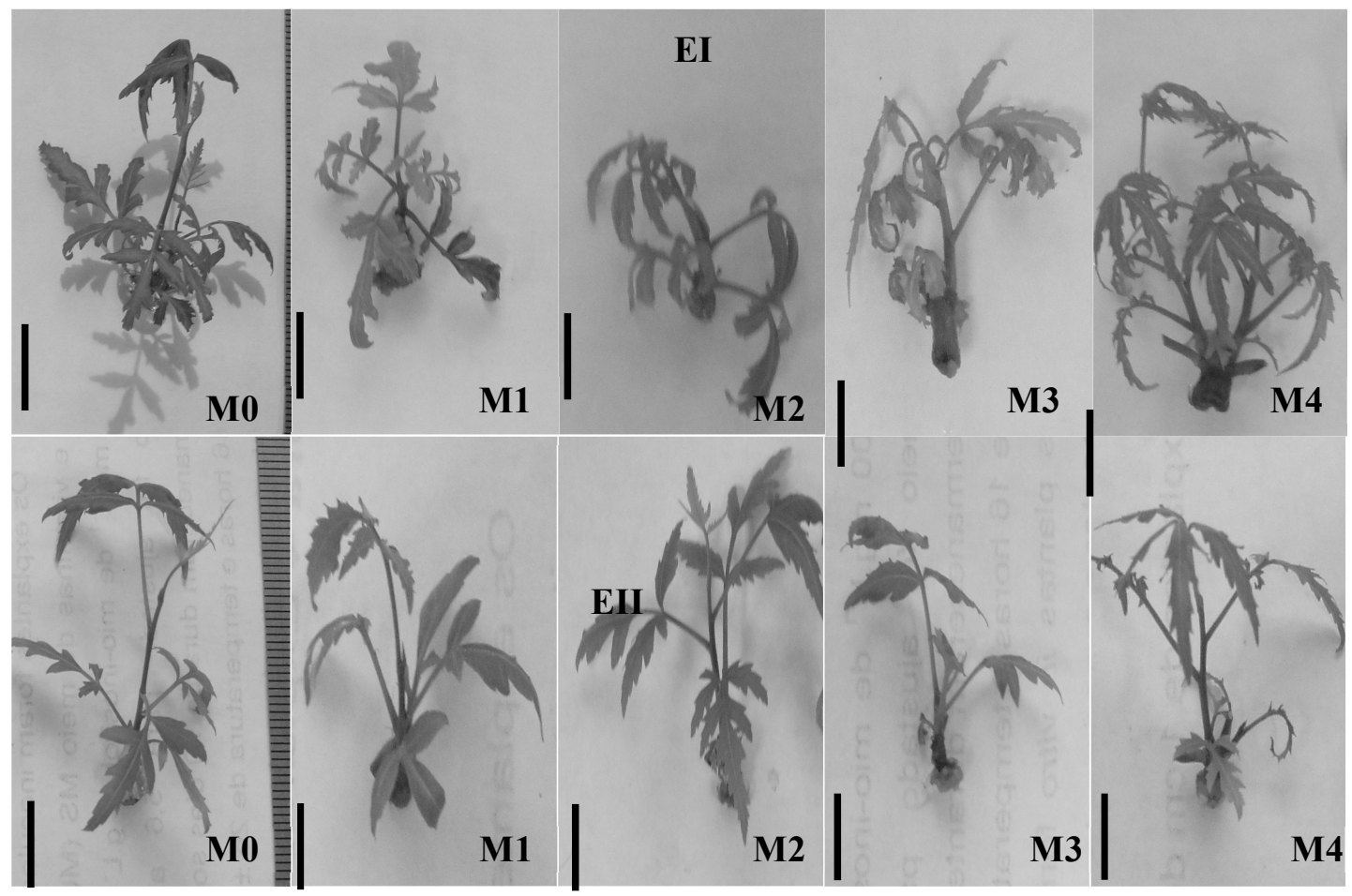

Figure 2. Neem plants grown in vitro on DKW medium supplemented with BAP (M0 - 0.225 mg. $\mathrm{L}^{-1}$ ) and the Bendazol fungicide (M1 - 50; M2 - 100; M3 - 200 e M4 - 400 mg. $\mathrm{L}^{-1}$ ) in experiments I (EI) and II (EII). Bars $=1,0 \mathrm{~cm}$.

There was no statistically significant difference in the height of the aerial part of the micropropagated neem plant between the concentrations of Bendazol and between the two experiments. A higher elongation of explants was observed in media containing BAP (M0) for both experiments; the averages were 3.5 and $4.2 \mathrm{~cm}$ in experiments I and II, respectively (Tables 1 and 2 and Fig. 2).

There was no rooting and no death of neem plant micropropagation. These results indicate that the fungicide used and phytoregulator act similarly in the explants with regard to the toxicity and action of the compound on the induction of the root system. Bacterial and fungal contamination were not observed during the 30 days of culture in any of the experiments.

\section{Discussion}

The lack of statistical differences in the development of the lateral bud, the formation of calluses and shoot height suggest that the Bendazol fungicidal acts analogously to the growth regulator BAP on neem micropropagation, both at lower and higher applied dosages. Tests are required to determine the efficacy of Bendazol use in different clonal neem lineages because the genotype is one of the determining factors during in vitro plant regeneration. The most frequently use of Bendazol fungicide on micropropagation is for contamination control (Niedz and Bausher, 2002; Sem et al 2013). However, some previous experiments indicates that fungicides and others compounds can induce a phytoregulator response (Ružić et al 2008).

Experimentation with the growth regulator $\mathrm{BAP}$, a commercial cytokinin commonly used in micropropagation, has demonstrated that it can activates responsive cells that function in triggering of several plant metabolic pathways. The use of BAP for in vitro induction of the buds formation from nodal neem segments, was 
described by Arora et al. (2010), using 1.11 $\mathrm{mM}$ of BAP. The results suggested that the Bendazol fungicide acts by a similar mechanism in the same metabolic pathways as BAP.

The results of this study are similar to those obtained from surveys carried out with the fungicide Benomyl. Moreira (1993) and Silva et al. (2002) have shown the positive effects of Benomyl on the in vitro cloning of Citrus sunki and Ananas comosus, respectively. In studies with soybean and horseradish (Skene, 1972) in addition to asparagus (Yang, 1976), Benomyl affected the plant hormone cytokinin. Thus, it is likely that Bendazol has chemical characteristics that allow a similar action as that of Benomyl.

Baker, cited by Yang (1976) also noted that Benomyl has a similar effect on cytokinin. It is believed that this hormonal effect results either from changes in the active ingredient during autoclaving of the medium [due to unknown components that are part of the manufacture of the fungicide (Skene, 1972)], or even by having a structural similarity to the cytokines (Thomas, 1973, Pulate (2016).

Flores et al. (1999) cultivated in vitro apple explants and found that Benomyl was harmful to the multiplication of the apple tree, to sprouting and also to bud formation. Carvalho et al. (1996) found that Benomyl had no effect on the number and size of Coffea arabica L. sprouts. Dane and Dalgiç (2005) reported that benomyl has some negative effects on mitotic divisions in onion root tip cells. These results indicate that, despite the successful use of Bendazol during neem micropropagation, it cannot be generally applied to the micropropagation of all plant cultures; each species may have specific responses to the compound.

Colombo et al. (2004) using the fungicide Chlorothalonil in the culture medium found that the best fungicide concentrations that influence the in vitro propagation of Orchids (Cattleya loddigesii, Laelia lundii) are in the range of 0.1 to $0.2 \mathrm{~g}$
$\mathrm{L}^{-1}$. In the case of in vitro neem cultivation, no significant differences between Bendazol doses were observed in the ability to induce a response. Therefore, it is possible to adopt the lowest dose $\left(50 \mathrm{mg} \mathrm{L}^{-1}\right)$ for the propagation of this species.

By contrast, Watt, Blakeway and Gauntlett (1996) found that both Benomyl (0.5 $\mathrm{g} \mathrm{L}^{-1}$ and $\left.1.0 \mathrm{~g} \mathrm{~L}^{-1}\right)$ as Chlorothalonil (0.25 $\mathrm{g} \mathrm{L}^{-1}$ and $\left.0.5 \mathrm{~g} \mathrm{~L}^{-1}\right)$ were harmful to Eucalyptus grandis when added to the culture medium. These authors observed that the survival of explants was significantly compromised, and the multiplication and regeneration of the plant was completely inhibited.

It can be inferred that the formation of calluses, observed in both experiments and five treatments, is probably related to Bendazol's ability to act as a plant regulator, requiring its presence only to enable responsive cells that operate in different physiological processes of the plant. The callus is characterized by a disorganized mass of partially undifferentiated cells that vary in type, size, content and cell wall thickness (Ikeuchi et al., 2013). Histological analyses of the calli obtained in this work are then evaluated to determine whether Bendazol treatment interferes with the characteristics of cells present in the callus.

It is possible that oxidation of the calluses maintained in the M1, M2, M3 and M4 treatments are related to the toxicity of the fungicide. However, this oxidation did not change with respect to Bendazol exposure times. Both explants exposed to fungicides for one week or for 30 days showed the same oxidation levels. Therefore, it is important to add antioxidant substances, such as activated charcoal or citric acid, to the culture medium to minimize any possible oxidative effects resulting from the Bendazol action.

Root formation was not observed in our study in the presence of the Benomyl fungicide in contrast to the presence of rooting plants in similar studies of chrysanthemum (Salgado et al., 2001) and pineapple (Silva et al., 2002). 
The absence of any evidence of death in the explants suggested that the selected Bendazol concentrations did not affect the survival of the resultant plants. By contrast, Oda et al. (2003) found that doses of Benomyl (1.00 $\left.\mathrm{g} \mathrm{L}^{-1}\right)$ and Chlorothalonil $\left(2.00 \mathrm{~g} \mathrm{~L} \mathrm{~L}^{-1}\right)$ were lethal to the orchid seedlings propagated in vitro. It is necessary to carry out tests with long duration and several subcultures to determine whether there is a cumulative toxic effect on the neem plants.

Fungal and/or bacterial contamination was not observed during the course of the two experiments, which could have resulted from the use of Bendazol in the culture medium as this is considered a systemic fungicide used to prevent potential contamination.

Replacement of BAP with Bendazol can reduce the large-scale production costs in the micropropagation neem plants. According to the Institute of Agricultural Economics (2006), a litre of Bendazol costs R\$ 24.00 (value provided by MFRURAL), however one BAP gram costs R\$206.00 (value supplied by Sigma). Therefore, the production of 1,000 neem seedlings using Bendazol promotes a cost reduction of approximately $93 \%$ compared to BAP on the in vitro multiplication step. Thus, the use of low doses of agrochemicals such as fungicides in the in vitro culture medium of some plant species (such as neem) may satisfactorily replace the synthetic cytokinin, which is ultimately important in reducing production costs.

\section{References}

Amaral CLF, Silva AB. Melhoramento Biotecnológico de Plantas Medicinais. Revista Biotecnologia Ciência e Desenvolvimento, Viçosa- MG 2003; 30: 55-59.

Arora K, et al. Rapid in vitro cloning of a 40 year-old tree of Azadirachta indica A. Juss. (Neem) employing nodal stem segments. Agroforestry Systems 2010; 78 (1): 53-63.

Cabral GB, Pires MVV, Lacerda AL, Carneiro VTC. Introdução in vitro, micropropagação e conservação de plantas de Brachiaria sp. Brasília, DF: Embrapa Recursos Genéticos e Biotecnologia. Technical Communication 2003; 101:1-4.

Carvalho GR, et al. Influência do Benomyl e Benzilaminopurina sobre a proliferação in vitro de café Cv. Cutuaí. Revista Ceres, Viçosa- MG 1996; 43 (248): 402-408.

Colombo LA, et al. Influência do fungicida clorotalonil no desenvolvimento vegetativo e no enraizamento in vitro de duas espécies de orquídeas brasileiras. Acta Scientiarum Agronomy, Maringá 2004; 26 (2): 253-258.

Dane F, Dalgiç Ö. The effects of fungicide benomyl (benlate) on growth and mitosis in onion (Allium cepa 1.) root apical meristem. Acta Biologica Hungarica 2005; 56 (1-2):119-128.

Driver JA, Kuniyuki AH. In vitro propagation of paradox walnut root stock. Hortscience, Alexandria 1984; 19 ( 4): 507-509.

Flores $\mathrm{R}$, et al. Efeito da sacarose e do benomyl na multiplicação in vitro da macieira. Pesq. Agropec. Bras, Brasília 1999; 34 (12): 2363-2368.

Giladi I, et al. Method for asseptid culture for bud explants form Citrus trees. Sci. Hortic, Amsterdam 1979; 10: 357-362.

Instituto de Economia Agrícola. Anuário de Informações Estatísticas da Agricultura. São Paulo, 2006; 116. (Série Informações Estatísticas da Agricultura). Anuário IEA 2005.

Ikeuchi M, et al. Plant Callus: Mechanisms of Induction and Repression. The Plant Cell, 2013; 25: 3159-3173.

Moreira M. Efeitos do Benomyl e do Ácido Indolbutírico na propagação in vitro do porta enxerto Citrus sinki Hort. ex. Tan. 1993. 56 f. Dissertação (Mestrado) Esal, Lavras, 1993.

Muthu H. et al. Synthesis of biodiesel from neem oil using sulfated zirconia via tranesterification. Brazilian Journal Of Chemical Engineering, 2010. p. 601-608.

Niedz RP, Bausher MG. Control of in vitro contamination of explants from green 
house and field-grown trees. 2002; In Vitro Cell. Dev. Biol 38:468-471.

Neves BP et al. Utilização Medicinal do Nim. Revista Eletrônica Faculdade Montes Belos, Goiás 2005; 1 (1): 107-118.

Oda ML, et al. Avaliação da fitotoxicidade de fungicidas e germicida na propagação in vitro de Oncidium varicosum Lindl. (Orchidaceae) para o controle de microorganismos. Semina: Ciências Agrárias, Londrina 2003; 24 (2): 273-276.

Ogbuewu IP, et al. The growing importance of neem (Azadirachta indica A. juss) in agriculture, industry, medicine and environment: A review. Res. J. Med. Plant, 2011; 5: 230-245.

Orwa C, et al. Agroforestree Database:a tree reference and selection guide version 4.0. 2009.

Paes JB, et al. Eficiência dos óleos de nim (Azadirachta indica) e de mamona (Ricinus communis) na proteção da madeira de sumaúma (Ceiba pentandra) contra cupins xilófagos em ensaio de preferência alimentar. Revista Árvore, Viçosa- MG 2011; 35 (3): 751-758.

Pulate PV. Effect of systemic fungicide benlate (benomyl) on seedling germination and growth in Allium cepa 1 . Int J Pharm Bio Sci, 2016; 7 (2):418 - 423.

Ružić D, Vujović T, Milenković S, Cerović $\mathrm{R}$, Miletić R. The infuence of Imidazole fungicides on multiplication in vitro of pyrodwarf pear rootstock. Austr J of Crop Sci,2008; 1 (2):63-68.

Rodrigues $\mathrm{M}$, et al. Morfogênese in vitro de nim a partir de explantes cotiledonares. Revista Árvore, Viçosa- MG, 2009; 33 (1): 21-26.

Salgado SML, et al. Efeito da utilização de tdz e benomyl na micropropagação do crisântemo (Dendranthema morifolium). Ciênc. Agrotec, Lavras, 2001; 25 (2): 274280.

Sen MK, et al. In vitro sterilization protocol for micropropagation of Achyranthes aspera L. node. International Res $\mathrm{J}$ of Biotec, 2013; 4 (5): 89-93.

Silva $A B$, et al. Influência da benzilaminopurina e do benomyl na proliferação in vitro de abacaxizeiro. Ciênc. Agrotec, Lavras 2002; 26 (6): 1190-1196.

Silva FAS, Azevedo CAV. Principal Components Analysis in the Software Assistat-Statistical Attendance. In: World congress on computers in agriculture, n.7, Reno-NV-USA: American Society of Agricultural and Biological Engineers, 2009.

Souza AS, et al. Introdução à cultura de tecidos de plantas. In: Souza AS, Junghans TG (Eds.). Introdução à micropropagação de plantas. Cruz das Almas: Embrapa Mandioca e Fruticultura Tropical, 2006; p. 11-37.

Skene KGM. Cytokinin-like properties of the systemic fungicide benomyl. Horticult. Sci. 1972; 47: 179-182.

Thomas TH. Growth regulatory effect of three benzilamidazole fungicides on the germination of celery (Apium graveolens) seeds. Ann. Appl. Biol. 1973; 74: 233-238.

Tiwari V, Tiwari NK, Sing BD. Shoot bud regeneration from different explants of Bacopa monniera (L.) Wettst. by trimethoprim and bavistin. Plant Cell Rep. 2006; 25 (7): 629-635.

Watt MP, Blakeway FC, Gauntlett BA. Effect of anti-fungal agents on in vitro cultures of Eucalyptus grandis. S. Afr. J. For. 1996. p. 23-27.

Vidigal, DS et al. Germinação e morfologia desenvolvimento pós-seminal de sementes de nim-indiano (Azadirachta indica A. Juss. - Meliaceae). Revista Brasileira de Sementes, Londrina, 2007; 29 (03): 39-46.

Yang HJ. Effect of Benomyl on Asparagus officinalis L. shoot and root development in culture media. Hortscience, 1976; 5 (11): 473-474. 